\title{
COMMENTS ON THE MEDICAL ASPECT OF THE BATTLE OF WATERLOO, $1815^{*}$
}

by

\section{J. M. MATHESON}

THE image of the Medical Department of the Army in the twenty years preceding 1815 had not been an impressive one. With a few notable exceptions the hospital staffs, in particular the 'mates', the purveyors and the apothecaries, had had a very bad name since the war started against the French in Flanders in 1793. Regrettably John Hunter who was Surgeon-General died in the same year, a year when a great expansion of the Army took place and brought in many broken-down practitioners, drunken apothecaries and rogues of every description. Indeed it has been said that in 1794 the mismanagement of hospitals had been exceeded only by the chaos in the Army as a whole, and this in turn by government mismanagement, and misappropriation of public funds. And the disastrous Walcheren expedition of 1809 had done little to inspire confidence.

In the Peninsular Campaign of 1808-1812 this situation was only slightly better, and it was Napier (1812) in his History of the Peninsular War who wrote, 'where one soldier died for want of surgical skill, hundreds perished from the absence of medical organisation', and stated that the want of money, and the indifference of the part of the home authorities, greatly frustrated the unceasing efforts of Wellington and Sir James McGrigor (1771-1858) to better the lot of the sick and wounded.

Between the regimental hospitals and the military hospitals there were no intermediate medical units of the nature of field ambulances. Neither were there medical vehicles to evacuate regimental sick and wounded to the hospitals: this depended partly on local resources and partly on the casual assistance of a weak, usually illdisciplined wagon train, furnishing only three wagons to a Division for general purposes.

By comparison, the French seem to have had a more efficient casualty evacuation system. It is said that it was remarkable how rapidly the French sick and wounded were whisked away from the battlefield borne by stretcher bearer parties (Corps de Brancardiers) which had been introduced earlier by Baron Percy. Evacuation was then effected by Larrey's well disciplined ambulance cart units (Ambulance Volantes) consisting of horse-drawn well sprung two-wheeled and four-wheeled covered carts.

A number of promising measures were effected after 1800: entrance examinations for surgeons' mates; the establishment, in 1806, at Edinburgh University of a Chair of Military Surgery with John Thomson (1765-1846), who had little, if any, military surgical experience, as the first incumbent. Then in 1809 the transference of control of the Army Medical Department from part-time civilian physicians and surgeons to full-time serving and experienced regular medical officers.

* A paper read to a meeting of the Osler Club of London 29 March 1965. 


\section{News, Notes and Queries}

Meanwhile, in the Peninsula, able men like Guthrie, a surgeon, and McGrigor, a medical administrator, and a few others toiled hard to improve the standards of the medical services. Guthrie was retired in 1814, and McGrigor's appointment on 13 June 1815 as Director-General of the Army Medical Department came far too late significantly to influence the medical arrangements for the battle of Waterloo.

In March 1815 Europe was shattered by the news of Napoleon's escape from Elba and of his return to Paris. Having gathered his forces, he began to move northwards towards the Low Countries where the British and Prussian forces were gathering.

The small British garrison of some 5,000 Peninsular War Veterans in the Low Countries was hurriedly increased to about 71,000 with both inadequately trained and inexperienced British reinforcements and with Hanoverian troops. Dutch and Belgian troops of mixed quality brought the strength of Wellington's command up to 106,000 .

The medical establishment for the British force was inadequate as it had been intended for an Army of only 40,000 (Kempthorne 1933). Coupled with this underestimation there was probably difficulty in obtaining sufficient experienced doctors and hospital staffs for the hurriedly expanded Army. It consisted of a P.M.O. (J. R. Grant), his headquarter staff, general hospitals and regimental surgeons and their assistants. Five General Hospitals were established for British and Hanoverian troops at Ostend, Ghent, Bruges, Brussels and Antwerp.

\section{THE BATTLE OF WATERLOO}

Napoleon's first encounter with the British and Prussian armies took place on 16 June 1815. Blucher's Army had to withdraw from Ligny to Wavre and Liège, while Wellington, having suffered over 3,000 casualties at Quatre Bras, moved back northwards and massed his forces on 17 June on the rising ground at Waterloo, with the Forest of Soignes behind him. On that night there was a torrential thunderstorm soaking both armies and the field of battle. When they rose on the morning of 18 June most of the men were numbed and saturated in the bleak, cold and damp wind, but by 10 a.m. the men and their clothes and muskets were almost dried out.

On the battlefield Wellington had 66,000 men and Napoleon over 70,000. The battle began soon after 11 a.m. and raged throughout the day until about sunset (8 p.m.) when, helped by the belated appearance of the first elements of Blucher's Army, Wellington's force finally repelled the desperate attacks of the Imperial Guard and was able to advance, with the French in full retreat leaving 25,000 dead and 8,000 prisoners out of Napoleon's Army of over 70,000. (Figures of strengths and casualties are approximate).

The British and Hanoverian element of the Allied Army with a strength of 32,900 suffered 10,700 casualties (including 7,000 wounded).

\section{MANAGEMENT OF THE WOUNDED}

The Regimental Surgeons must have been exhausted with their day-long toil among the ever mounting number of wounded and with a lack of proper facilities and water (Gibney 1896), for most sources of water within three miles of the battlefield were alleged to have been polluted with blood (Barnes) and corpses (Jones 1852).

'The rudimentary medical services of the allied armies were swamped from the beginning . . . Many of the Allied wounded of lower rank spent two nights and a day, 


\section{News, Notes and Queries}

some even longer, without receiving assistance. The wonder is that they recovered at all . . . even after a month the churches near Waterloo were still full of wounded' (Naylor 1960). Carts and any form of transport, all very scarce, were used to take the wounded to Brussels. (Vansittart 1960). For those who could walk it was a weary and halting journey.

In Brussels the arrangements for the reception of the wounded were also totally inadequate and when, as much as eleven days after the battle, the distinguished surgeon, Sir Charles Bell, arrived in Brussels, he found preparations still incomplete (Pettigrew 1840). Great exertions and sacrifices were made by the inhabitants of Brussels and the neighbouring towns to comfort, and even house, the wounded who had survived the jolting ride on the primitive and crowded roads from the battlefield (Eaton 1817).

The task facing the hospital staffs, and particularly the surgeons, was herculean. It was indeed fortunate that a military surgeon of Dr. George James Guthrie's extensive Peninsular experience was there for 5 weeks (at his own expense), and even Sir Charles Bell, a much later arrival, spent eight days of ceaseless operating on the wounded (Bell 1870). In spite of this exhausting experience both surgeons kept careful notes of their cases and Bell's water-colour paintings are still treasured in the Royal Army Medical College, Millbank.

John Thomson, the Professor of Military Surgery at Edinburgh, visited the hospitals in Belgium, but not before 8 July 1815-three weeks after the battle. His Report published in 1816 makes interesting reading. He commented favourably on the condition of the hospitals and the devoted care of the patients both by the military staff and by the people of Brussels. He considered that the wet weather and exposure had had little effect on the wounded, though he might have overlooked those who never reached Brussels or who died before he reached the town.

\section{WOUND SHOCK AND GANGRENE}

Wound shock as a condition requiring resuscitative treatment other than to delay operation was not then generally recognised. Indeed, Guthrie (1815) discussing amputation in gunshot wounds refers only obliquely to shock, writing, 'If a soldier at the end of two, four, or six hours after the injury has recovered from the general constitutional alarm occasioned by the blow, his pulse becomes regular and good, his stomach easy, he is less agitated, his countenance revives, and he begins to feel pain, stiffness and uneasiness in the part: he will now undergo the operation with greatest advantage ... The active management of shock can only be surmised from this quotation from the letter of Lt.-Col. Ponsonby who wrote: 'I had received seven wounds: a surgeon slept in my room, and I was saved by excessive bleeding' (Naylor 1960).

Apart from the wounds inflicted by lance, sabre and bayonet, the damage caused by cannon-ball, grapeshot and musket ball, was probably comparatively less than that inflicted by the explosive viciousness of our modern high velocity missiles, nevertheless infection was inevitable, especially with a delay in evacuation, and hospital gangrene and tetanus were rife.

Hospital gangrene, as it was described by the great French military surgeon Larrey, 


\section{News, Notes and Queries}

and by Guthrie (1815), was interpreted by Bowlby (1919), to be of the nature of a spreading ulceration in suppurating wounds and in no way to resemble the classical and terrible acute gas gangrene the incidence of which seems, in history, to have been highest in the early years of the 1914-18 war.

Until John Hunter reported on his surgical experiences in the 1761 Belleisle expedition, military surgery had not advanced for nearly 200 years since the death of Paré in 1590. It was Larrey and Guthrie who gave military surgery great impetus. Nevertheless the treatment of battle wounds still only consisted of dressings, compresses, bleeding, the surgical removal of missiles, blood vessel ligation, and amputation.

Mortality was high with and without amputation. Before 1800 Hunter had advocated delay in amputation until wound inflammation was well established. Larrey and Guthrie each in their own spheres strongly advised amputation as soon as possible after wounding, preferably within 24 hours, and Guthrie preferred the circular method in most cases. It seems that Guthrie's practice was 'when in doubt amputate' and Thomson estimated that at Waterloo some 500 amputations were done: one-third of these before the onset of inflammation.

\section{REFERENCES}

BARnes, R. M., A History of the Regiments and Uniforms of the British Army, London.

BOWLBY, SIR ANTHONY, Hunterian Oration on British Military Surgery in the time of Hunter and in the Great War, London, Adlard \& West Newman, 1919.

Eaton, Charlotte, Narrative of a Residence in Belgium during the Campaign of 1815, London, 1817.

GIBNEY, DR., Eighty Years Ago, London, Bellairs, 1896.

Gordon-TAYlor, Sir G., and Walls, E. W., Sir Charles Bell: His Life and Times, Edinburgh \& London, E. \& S. Livingstone, 1958.

GUTHRIE, G. J., On Gunshot Wounds of the Extremities, requiring the Different Operations of Amputation, London, 1815.

Johnson, Thomas, The works of that famous Chirurgien Ambroise Paré translated out of the Latin and compared with the French, 1634.

JoNes, George, The Battle of Waterloo, 1852.

Kempthorne, G. A., 'The Waterloo campaign', J. roy Army Med. Corps., 1933, 60, 52.

NAPIER, W. F. P., 'War in the Peninsula and in the South of France from 1807 to 1814', 2nd ed., Vol. 5, Book 19, p. 248, as also quoted by Elkington, H. P., J. roy. Army Med. Corps., 1911, 16, 103.

NAYLOR, JoHN, Waterloo, London, B. T. Batsford, 1960.

PetTigrew, Medical Portrait Gallery, Vol. II, London, 1840.

The Letters of Sir Charles Bell, London, Murray, 1870.

Thомson, J., Report on Observations made in the British Military Hospitals in Belgium after the Battle of Waterloo, Edinburgh, 1816.

VANSITTART, J., Surgeon James' Journal 1815, London, Cassell, 1960. 